\title{
Imidacloprid-induced oxidative stress in honey bees and the antioxidant action of caffeine
}

\author{
Kamila Vilas Boas Balieira, Meiriele Mazzo, Paulo Francisco Veiga Bizerra, \\ Anilda Rufino de Jesus Santos Guimarães, Daniel Nicodemo, Fábio Erminio Mingatto \\ College of Agricultural and Technological Sciences, São Paulo State University (Unesp), Dracena, SP, Brazil
}

Received 6 November 2017 - Revised 8 May 2018 - Accepted 19 July 2018

\begin{abstract}
The use of pesticides on crops contributes to the decline of bee populations, and in this sense, bioactive nutrients have been studied to counteract this effect. We suppose that caffeine might be one of these nutrients. We exposed honey bees (Apis mellifera L.) to 0.7 or $2.0 \mathrm{ng} / \mathrm{mL}$ imidacloprid, $5.0 \mu \mathrm{g} / \mathrm{mL}$ caffeine in syrup, or $5.0 \mu \mathrm{g} / \mathrm{mL}$ caffeine in syrup plus 0.7 or $2.0 \mathrm{ng} / \mathrm{mL}$ imidacloprid. After $72 \mathrm{~h}$, the oxidative status and the food intake were verified. Imidacloprid increased glutathione peroxidase and catalase activities. Caffeine alone or with $2.0 \mathrm{ng} / \mathrm{mL}$ imidacloprid also stimulated the activity of glutathione peroxidase but did not alter the effect of the insecticide on the catalase activity. A significant reduction in the concentration of the thiol group of proteins was observed in the two imidacloprid-fed groups, and the addition of caffeine protected these groups. Imidacloprid increased the malondialdehyde concentration while the addition of caffeine partially decreased this effect. Food intake was higher for bees treated with $2.0 \mathrm{ng} / \mathrm{mL}$ imidacloprid. Our results show that imidacloprid increased the food intake resulting in oxidative damage, which was partially reversed by caffeine. From these findings, it is inferred that caffeine treatments can be used to mitigate the sublethal effects of this insecticide on honey bees.
\end{abstract}

\section{Beekeeping / Insecticide / Lipid peroxidation / Neonicotinoids / Oxidative stress / Toxic effects}

\section{INTRODUCTION}

Bees are one of the pillars of sustainability since they significantly increase food production (McGregor 1976). The economic value of pollination performed by bees on agricultural crops worldwide is around 153 billion euros (Gallai et al. 2009). Thus, agricultural practices friendly to bees contribute to the optimization of bee pollination services of commercial crops and give better chance of success to beekeepers to produce honey (Morandin and Winston 2006; Aizen and Harder 2009; Van der Sluijs et al. 2013). However, deforestation, planting of largescale monocultures, and the use of pesticides are practices inherent to industrial agriculture that

Corresponding author: F. Mingatto,

fabio.mingatto@unesp.br

Manuscript editor: Monique Gauthier make it difficult to obtain great production of bee products and even involve recurrent bee colony losses (Paoletti 1999; Kremen et al. 2007; Johnson et al. 2010; Nicholls and Altieri 2013).

From all the possible reasons that can be related to bee decline, it is undeniable that pesticides are a major threat to bees. The impact of the use of agrochemicals on bees has been the subject of several scientific studies (Pham-Delègue et al. 2002; Krupke et al. 2012; Poquet et al. 2016; Kiljanek et al. 2016), since the effects of these products on non-target insects can be manifested through lethality but also through sublethal effects, which are of a more detailed diagnosis (Thompson 2001; Van Der Steen 2001; Thompson 2002; Brittain and Potts 2011). The intoxication of the bees can happen when they have direct contact or ingest contaminated food or even when contaminated wax is introduced into their hives (Rortais et al. 2005; Gill et al. 2012), 
resulting in individual and colony-level impacts (Desneux et al. 2007).

Imidacloprid is a neonicotinoid insecticide used in commercial formulations for pest control in numerous crops worldwide, which also presents high toxicity to bees (Decourtye et al. 2003, 2004; Faucon et al. 2005; Blacquière et al. 2012). The $\mathrm{LD}_{50}$ values of imidacloprid are 3.7 and $40.9 \mathrm{ng} / \mathrm{bees}$, orally and by contact, respectively (Schumuck et al. 2001). This insecticide is a neurotoxin specifically acting as antagonist of the nicotinic acetylcholine receptors, causing paralysis and death (Matsuda et al. 2001). Despite this lethal effect, other sublethal effects may manifest in bees exposed to imidacloprid, several of them already described in scientific papers (Blacquière et al. 2012). In addition, considering the effect on the energy metabolism, Nicodemo et al. (2014) demonstrated that imidacloprid affects energy production by bees' mitochondria and Nicodemo et al. (2018) showed that imidacloprid reduces lipophorin levels in honey bee hemolymph, but the effects of this insecticide on the cellular antioxidant system of these insects have not yet been described.

Aerobic metabolism continuously generates reactive oxygen species (ROS), which can cause oxidative damage to cellular components as proteins, nucleic acids, and membrane lipids. To avoid the undesired ROS effects, organisms have evolved a complex network of enzymatic and non-enzymatic antioxidant system (Farjan et al. 2012). The most important antioxidant enzymes identified in honey bees are superoxide dismutase (SOD), catalase (CAT), glutathione S-transferase (GST), and peroxidase while the non-enzymatic components are glutathione, $\mathrm{NAD}(\mathrm{P}) \mathrm{H}$, vitamins $\mathrm{C}$ and $\mathrm{E}$, albumin, uric acid, urea, creatinine (Weirich et al. 2002; Strachecka et al. 2014; Strachecka et al. 2015).

Caffeine (1,3,7-trimethylxanthine) is a lipidsoluble alkaloid, a component of the class of compounds known as methylxanthines (D'amicis and Viani 1993), which acts on the central nervous system (Albina et al. 2002). Caffeine is also known for its antioxidant properties (Lee 2000). Strachecka et al. (2014) studied the effect of caffeine on the longevity and antioxidant system of worker bees exposed to the pathogen Nosema spp. and demonstrated that the substance could be considered as a natural dietary supplement to increase the resistance of swarms to factors of stress. In this sense, the inclusion of caffeine in the feeding of Apis mellifera bees may be an alternative to the reduction of intoxication of hives by pesticides, and it is important to develop research in this area to find alternatives for the beekeeper. Here, we aimed to investigate the effects of imidacloprid on the cellular antioxidant system of honey bees and the potential antioxidant action of caffeine, determining the activities of some antioxidant enzymes (GPx and CAT), concentrations of non-enzymatic antioxidants $(\mathrm{GSH}$ and $\mathrm{NAD}(\mathrm{P}) \mathrm{H})$, as well as protein thiol groups and membrane lipid oxidation in bee thorax.

\section{MATERIAL AND METHODS}

\subsection{Chemicals}

All chemicals were of the highest available grade. Imidacloprid and caffeine were purchased from Sigma-Aldrich. All of the stock solutions were prepared by dissolving appropriate amounts of reagents with ultrapure water (Direct Q3, Millipore, Bedford, MA, USA) and stored at $4{ }^{\circ} \mathrm{C}$ until use.

\subsection{Treatments}

Africanized honey bees from Langstroth hives from the experimental apiary of São Paulo State University (Unesp), College of Agricultural and Technological Sciences, Dracena were used. Frames with sealed brood were introduced in an incubator maintained at $33{ }^{\circ} \mathrm{C}$ and $70 \%$ humidity. Samples with 20 newly emerged worker bees $(0-$ $24 \mathrm{~h}$ old) were collected and introduced in plastic cages with dimensions of $14 \mathrm{~cm}$ in length $\times 14 \mathrm{~cm}$ in width $\times 22 \mathrm{~cm}$ in height, with side ventilation slots, where they were fed with different diets, and this procedure was repeated three times for each treatment.

The stock solutions of imidacloprid and caffeine were diluted in syrup consisting of equal proportions of water and sugar to be provided for honey bees. The established treatments were: control (only syrup), syrup with addition of 
$0.7 \mathrm{ng} / \mathrm{mL}$ imidacloprid, syrup with addition of $2.0 \mathrm{ng} / \mathrm{mL}$ imidacloprid, syrup with $5.0 \mu \mathrm{g} / \mathrm{mL}$ caffeine, syrup with added caffeine plus $0.7 \mathrm{ng}$ / $\mathrm{mL}$ imidacloprid, and syrup with added caffeine plus $2.0 \mathrm{ng} / \mathrm{mL}$ of imidacloprid.

In each cage, $3 \mathrm{~mL}$ of the diet was provided soaked in $0.60 \mathrm{~g}$ of cotton in a plastic feeder. Experimental diets were provided during a period of $24 \mathrm{~h}$. Then, only syrup without additions was provided. The analyses were performed $72 \mathrm{~h}$ after the experimental diets were offered.

The doses of imidacloprid used in this study were selected by means of a pilot study in which the bees were submitted to different doses of the insecticide $(0.7,2.0$, and $3.3 \mathrm{ng} / \mathrm{mL})$. The bees did not survive at the highest dose tested $(3.3 \mathrm{ng} / \mathrm{mL})$, whereas we observed no mortality with doses of 0.7 and $2.0 \mathrm{ng} / \mathrm{mL}$. The dose of caffeine was selected from a previous study by Strachecka et al. (2014).

\subsection{Homogenate preparation}

Twenty bees were collected per treatment to obtain a pool of thoracic muscle. The thorax was dissected, and the homogenate was prepared according to Hoskins et al. (1956), with modifications. After separation of the head and abdomen, the thoraces of 20 bees were added to a porcelain mortor containing $20 \mathrm{~mL}$ of ice-cold medium composed of $250 \mathrm{mM}$ sucrose, $0.2 \mathrm{mM}$ EGTA, $0.1 \mathrm{mM}$ EDTA, $5 \mathrm{mM}$ HEPES-KOH ( $\mathrm{pH} 7.4$ ), and $0.1 \%$ BSA (bovine serum albumin), and subsequently macerated with porcelain pestle and filtered in gauze folded 8 times.

The protein concentration of the homogenate was determined using the biuret reaction with BSA as a standard (Cain and Skilleter 1987) and expressed as $\mathrm{mg}$ protein $/ \mathrm{mL}$ homogenate.

\subsection{Glutathione peroxidase activity}

The activity of glutathione peroxidase (GPx) was determined by an indirect method based on the oxidation of reduced glutathione (GSH) to oxidized glutathione (GSSG), with the consequent oxidation of NADPH catalyzed by glutathione peroxidase (Flohé 1984). The reaction system was composed of $1.5 \mathrm{~mL}$ containing: $1.0 \mathrm{mM} \mathrm{GSH}, 0.2 \mathrm{mM}$
NADPH, $0.25 \mathrm{mM} \mathrm{H}_{2} \mathrm{O}_{2}, 0.5 \mathrm{mM}$ EDTA, and $0.10 \mathrm{M}$ sodium phosphate buffer ( $\mathrm{pH} 7.6), 0.1 \%$ Triton X-100 and an aliquot of thorax homogenate corresponding to $1.5 \mathrm{mg}$ protein. After incubating the samples at $30{ }^{\circ} \mathrm{C}$ for $5 \mathrm{~min}, 10 \mu \mathrm{L}$ of $20 \mathrm{mM}$ NADPH was added, and the variation in absorbance was determined at a wavelength of $340 \mathrm{~nm}$ in a DU-800 spectrophotometer (Beckman-Coulter, Fullerton, CA, USA). The oxidation of $1 \mu \mathrm{mol}$ $\mathrm{NADPH} / \mathrm{min}$ was used as one unit of GPx activity. The specific activity was expressed as unit per mg of protein. We performed two assays (cuvettes) for each one of the three replicates per treatment group containing 20 bees each.

\subsection{Catalase activity}

The evaluation of catalase enzyme activity was performed with an aliquot of thorax homogenate corresponding to $1.75 \mathrm{mg}$ protein in $1.75 \mathrm{~mL}$ of potassium phosphate buffer (50 mM, pH 7). The reaction was started by adding $200 \mu \mathrm{L}$ of $10 \mathrm{mM}$ $\mathrm{H}_{2} \mathrm{O}_{2}$. The variation in absorbance was determined at a wavelength of $230 \mathrm{~nm}$ in a DU-800 spectrophotometer (Beckman-Coulter, Fullerton, CA, USA). Catalase activity was defined as the amount of enzyme required to decompose $1 \mathrm{nmol}$ of $\mathrm{H}_{2} \mathrm{O}_{2}$ per minute at $25^{\circ} \mathrm{C}$. The specific activity was expressed as unit per mg of protein (Aebi 1974). We performed two assays (cuvettes) for each one of the three replicates per treatment group containing 20 bees each.

\subsection{Glutathione assay}

The levels of GSH were determined by a fluorometric reaction with $o$-phthalaldialdehyde (OPT) (Hissin and Hilf 1976). An aliquot of thorax homogenate corresponding to $1 \mathrm{mg}$ protein was added to the medium (125 mM sucrose, $65 \mathrm{mM} \mathrm{KCl}$, and $10 \mathrm{mM}$ HEPES-KOH, $\mathrm{pH}$ 7.4) to a final volume of $1 \mathrm{~mL}$ and treated with $0.5 \mathrm{~mL}$ of $13 \%$ trichloroacetic acid. The mixture was stirred and then centrifuged at $9000 \times g$ for $3 \mathrm{~min}$. Aliquots $(100 \mu \mathrm{L})$ of the supernatant were mixed with $2 \mathrm{~mL}$ of $100 \mathrm{mM} \mathrm{NaH}_{2} \mathrm{PO}_{4}$ buffer at $\mathrm{pH} 8.0$ containing $5 \mathrm{mM}$ EGTA. One hundred microliters of an OPT solution $(1 \mathrm{mg} / \mathrm{mL})$ was added, and the fluorescence was measured 
15 min later in an RFPC 5301 spectrofluorometer (Shimadzu, Tokyo, Japan) using 350/420 nm as the excitation/emission wavelength pair.

For the GSSG assay, $250 \mu \mathrm{L}$ of the initial supernatant was treated with $250 \mu \mathrm{L}$ of $0.04 \mathrm{M}$ $\mathrm{N}$-ethylmaleimide and subjected to the same mixing procedure as OPT. The concentrations of GSH and GSSG are expressed in nmol/mg protein estimated using respective GSH and GSSG standard curves. We performed two repetitions (tubes) for each one of the three replicates per treatment group containing 20 bees each.

\subsection{Determination of $\mathrm{NAD}(\mathrm{P}) \mathrm{H}$ level}

An aliquot of thorax homogenate corresponding to $2 \mathrm{mg}$ protein was added to the medium (125 mM sucrose, $65 \mathrm{mM} \mathrm{KCl}$, and $10 \mathrm{mM}$ HEPES-KOH, $\mathrm{pH}$ 7.4) to a final volume of $2.0 \mathrm{~mL}$ and centrifuged at $8000 \times \mathrm{g}$ for $3 \mathrm{~min}$. The supernatant was collected, and the fluorescence was measured in a spectrofluorometer (Shimadzu-RFPC 5301, Tokyo, Japan) using $366 / 450 \mathrm{~nm}$ as the excitation/emission wavelength pair. The data are expressed in relative fluorescence units (RFU), which are positively related with the concentration of the reduced form of pyridine nucleotides (Blacker et al. 2014). We performed two repetitions (cuvettes) for each one of the three replicates per treatment group containing 20 bees each.

\subsection{Oxidation of protein thiol groups}

The concentration of thiol (-SH) groups of proteins was determined using the Ellman reagent according to Sedlak and Lindsay (1968) with some modifications. An aliquot of thorax homogenate corresponding to $5 \mathrm{mg}$ protein was treated with $1 \mathrm{~mL}$ of $5 \%$ trichloroacetic acid (TCA) containing $5 \mathrm{mM}$ EDTA and subjected to centrifugation at $2500 \times \mathrm{g}$ for $5 \mathrm{~min}$. The protein precipitate was washed twice with the same TCA-EDTA solution. The proteins were redissolved in $3 \mathrm{~mL}$ of $0.1 \mathrm{M}$ Tris- $\mathrm{HCl}$ buffer, $\mathrm{pH} 7.4$, containing 5 mM EDTA and $0.5 \%$ sodium dodecyl sulfate. Aliquots of this

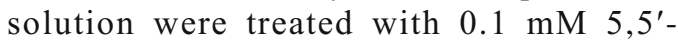
dithiobis(2-nitrobenzoic)acid (DTNB) dissolved in $2 \mathrm{~mL}$ of Tris-EDTA buffer, $\mathrm{pH}$ 8.6. The samples were incubated in the dark, and the absorbance was measured at $412 \mathrm{~nm}$ in a DU-800 spectrophotometer (Beckman-Coulter, Fullerton, CA, USA), and the values subtracted from a "blank" obtained by treating the samples with $5 \mathrm{mM} \mathrm{N}$ ethylmaleimide before the reaction with DTNB. The concentration of thiol groups was determined using $\varepsilon=13,600 \mathrm{M}^{-1} \mathrm{~cm}^{-1}$. We performed two repetitions (tubes) for each one of the three replicates per treatment group containing 20 bees each.

\subsection{Membrane lipid peroxidation assay}

The level of lipid peroxidation (LPO) was estimated by malondialdehyde (MDA) generation (Buege and Aust 1978). An aliquot of thorax homogenate corresponding to $5 \mathrm{mg}$ protein was added to a glass test tube. Following the addition of $0.2 \mathrm{~mL}$ of $8.1 \%$ SDS, $1.5 \mathrm{~mL}$ of $20 \%$ acetic acid and $1.5 \mathrm{~mL}$ of $0.67 \%$ thiobarbituric acid (TBA, aqueous solution), glass-distilled deionized water was added to a final volume of $4 \mathrm{~mL}$. The mixture was incubated for $60 \mathrm{~min}$ at $85^{\circ} \mathrm{C}$. The MDA-TBA complex was extracted with $5 \mathrm{~mL}$ of n-butanol, and the absorbance was measured at $535 \mathrm{~nm}$ with an NI 2000 UV spectrophotometer (NOVA Instruments, Piracicaba, SP, Brazil). The MDA concentration was determined directly from the molar extinction coefficient of the MDA-TBA complex of $1.56 \times 10^{5} \mathrm{M}^{-1} \mathrm{~cm}^{-1}$ and represented as nmol $\mathrm{MDA} / \mathrm{mg}$ protein. We performed two repetitions (tubes) for each one of the three replicates per treatment group containing 20 bees each.

\subsection{Evaluation of the median survival of bees}

The median survival of honey bees treated with the experimental diets on day 0 was verified for $72 \mathrm{~h}$. The 360 workers were confined in 18 plastic cages with dimensions of $14 \mathrm{~cm}$ in length $\times 14 \mathrm{~cm}$ in width $\times 22 \mathrm{~cm}$ in height, with side ventilation slots, three cages per treatment. The cages were maintained at a controlled temperature $\left(33^{\circ} \mathrm{C}\right)$ and relative humidity $(70 \%)$ in an incubator. The dead bees were counted and removed from the cages daily. After the 24-h period with experimental diets available to bees, control diet was offered ad libitum for all insects. 


\subsection{Consumption of syrups}

Before feeding the bees, each cotton swab already soaked in the respective diet $(3 \mathrm{~mL})$ was weighed and then placed in the feeder inside the cage. After $24 \mathrm{~h}$ of diet ingestion, the cotton soaked with syrup was weighed again to evaluate the food intake by the workers. The mean weight loss due to evaporation $(\sim 18 \%)$ was discounted and the values obtained were divided by the number of bees present in the cage, considering the mortality rate during the test.

\subsection{Statistical analysis}

A completely randomized design with six treatments was used. Each treatment was composed of three replicates of plastic cages with 20 bees each (a total of 360 bees were tested). The statistical significance of the experimental data of the effects on the antioxidant system was determined by the analysis of variance (ANOVA) and the means compared by the Newman-Keuls test. The median survival of the bees was analyzed by the Kaplan-Meier non-parametric method. The diet intake was submitted to ANOVA, and the means were compared by the Tukey test. The analyses were performed using GraphPad Prism version 4.0 for Windows (GraphPad Software, San Diego, CA, USA). Values of $p<0.05$ were considered significant.

Data availabilityThe datasets during and/or analyzed during the current study are available from the corresponding author on reasonable request.

\section{RESULTS}

\subsection{Glutathione peroxidase activity}

We observed dose-dependent increase in the GPx activity in the thorax homogenate of the bees in the groups treated with $0.7 \mathrm{ng} / \mathrm{mL}$ imidacloprid (Newman-Keuls test, $\mathrm{q}=3.7, p<0.05$ ) and $2.0 \mathrm{ng} / \mathrm{mL}$ imidacloprid (Newman-Keuls test, $\mathrm{q}=7.7, p<0.01$ ) compared to the control group. A similar effect was found in the caffeine-treated group (Newman-Keuls test, $\mathrm{q}=6.4, p<0.01$ ). The addition of caffeine together with imidacloprid did not prevent the increase in enzyme activity (Table I).

\subsection{Catalase activity}

We also observed dose-dependent increase in the CAT activity in the thorax homogenate of the bees in the groups treated with $0.7 \mathrm{ng} / \mathrm{mL}$ imidacloprid (Newman-Keuls test, $q=4.3$, $p<0.05$ ) and $2.0 \mathrm{ng} / \mathrm{mL}$ imidacloprid (Newman-Keuls test, $\mathrm{q}=7.0, p<0.01)$ compared to the control group. Caffeine also increased the CAT activity (Newman-Keuls test, $q=5.6$, $p<0.05)$. No changes in the effect of imidacloprid were observed when caffeine was added to the diet (Table I).

\subsection{Oxidative state of glutathione}

Treatments with $0.7 \mathrm{ng} / \mathrm{mL}$ imidacloprid, $2.0 \mathrm{ng} / \mathrm{mL}$ imidacloprid, or caffeine had no effect on GSH concentration compared to the control group. A significant increase of the tripeptide glutathione in the reduced form (GSH) was observed only in the treatment with $2.0 \mathrm{ng} / \mathrm{mL}$ imidacloprid plus caffeine (Newman-Keuls test, $\mathrm{q}=5.3, p<0.05)$. A similar effect was observed with respect to the GSSG concentration (Newman-Keuls test, $\mathrm{q}=6.8, p<0.01$ ) (Table II). Despite the above-mentioned results, when calculating the GSH/GSSG ratio, we observed no effect of any of the treatments on the oxidative state of glutathione (Newman-Keuls test, $p>0.05$ ).

\subsection{Oxidative state of pyridine nucleotides (NAD(P)H)}

No significant changes were observed in $\mathrm{NAD}(\mathrm{P}) \mathrm{H}$ concentration in the bees' thorax homogenate in any of the treatments (Table II) (Newman-Keuls test, $p>0.05$ ).

\subsection{Oxidative state of protein thiol groups}

The treatments with imidacloprid promoted a significant reduction in the concentration of thiol (-SH) groups of proteins in the thorax homogenate of the bees in relation to the control group (Newman-Keuls test, $\mathrm{q}=7.3, p<0.01$ to $0.7 \mathrm{ng} / \mathrm{mL}$ 
Table I. Activity of antioxidant enzymes in the thorax homogenate of the bees $72 \mathrm{~h}$ after exposition to the imidacloprid and/or caffeine

\begin{tabular}{|c|c|c|c|c|c|c|}
\hline \multirow[t]{2}{*}{ Parameter } & \multicolumn{6}{|l|}{ Treatments } \\
\hline & $\begin{array}{l}\text { Control } \\
\text { (only syrup) }\end{array}$ & $\begin{array}{l}\text { Caffeine } \\
(5 \mu \mathrm{g} / \mathrm{mL})\end{array}$ & $\begin{array}{l}\text { Imidacloprid } \\
(0.7 \mathrm{ng} / \mathrm{mL})\end{array}$ & $\begin{array}{l}\text { Imidacloprid } \\
(2.0 \mathrm{ng} / \mathrm{mL})\end{array}$ & $\begin{array}{l}\text { Imidacloprid } \\
(0.7 \mathrm{ng} / \mathrm{mL})+ \\
\text { caffeine } \\
(5 \mu \mathrm{g} / \mathrm{mL})\end{array}$ & $\begin{array}{l}\text { Imidacloprid } \\
(2.0 \mathrm{ng} / \mathrm{mL})+ \\
\text { caffeine } \\
(5 \mu \mathrm{g} / \mathrm{mL})\end{array}$ \\
\hline $\begin{array}{c}\text { GPx }(\mathrm{U} / \mathrm{mg} \\
\text { protein) }\end{array}$ & $0.33 \pm 0.01^{\mathrm{a}} \mathrm{A}$ & $1.20 \pm 0.09 \mathrm{~B}^{\mathrm{b}}$ & $0.77 \pm 0.07 \mathrm{~B}$ & $1.38 \pm 0.14 \mathrm{~B}$ & $1.29 \pm 0.28 \mathrm{~B}$ & $1.95 \pm 0.24 \mathrm{C}$ \\
\hline $\begin{array}{c}\text { CAT (U/mg } \\
\text { protein) }\end{array}$ & $1.27 \pm 0.33 \mathrm{~A}$ & $3.55 \pm 0.55 \mathrm{~B}$ & $3.20 \pm 0.47 \mathrm{~B}$ & $4.13 \pm 0.23 \mathrm{~B}$ & $3.78 \pm 0.44 \mathrm{~B}$ & $3.36 \pm 0.05 \mathrm{~B}$ \\
\hline
\end{tabular}

$G P x$ glutathione peroxidase, $C A T$ catalase

${ }^{\text {a }}$ Results are expressed as the mean \pm standard error of the mean of three replicates with 20 bees/experiment

${ }^{\mathrm{b}}$ Means in the same line followed by different letters differ from each other (Newman-Keuls test, $p<0.05$ )

and $\mathrm{q}=7.6, p<0.01$ to $2.0 \mathrm{ng} / \mathrm{mL}$ ), indicating the oxidation of these groups. The addition of caffeine in the treatments with imidacloprid protected the thiol groups against the oxidation promoted by the insecticide (Table II).

\subsection{Membrane lipid peroxidation}

The peroxidation of membrane lipids was assessed by the measurement of malondialdehyde (MDA). All treatments had an effect on this parameter, increasing the concentration of MDA in relation to the control group. However, a dosedependent increase was observed in the groups treated with imidacloprid (Newman-Keuls test, $\mathrm{q}=7.8, p<0.01$ to $0.7 \mathrm{ng} / \mathrm{mL}$ and $\mathrm{q}=10.0, p<$ 0.001 to $2.0 \mathrm{ng} / \mathrm{mL}$ ), and, when added to the treatments with the insecticide, caffeine decreases its effect (Table II).

\subsection{Average survival of bees}

The treatment of the bees with the experimental diets did not interfere with the average survival of the bees during the $72 \mathrm{~h}$ of evaluation, even considering the control diet (data not shown).

\subsection{Consumption of diets}

Consumption was higher for bees treated with the diet containing $2.0 \mathrm{ng}$ imidacloprid per bee compared to the control group (Tukey test, $p<0.05)$. There was no difference in consumption among the groups of bees that received the other diets (Table III).

\section{DISCUSSION}

Oxidative stress is manifested by the misbalance between the production of reactive oxygen species (ROS) and the cellular antioxidant defense systems. This condition can lead to the damage of membranes, lipids, nucleic acids, and proteins (Hodgson and Smart 2001). Aerobic organisms have evolved protective systems, which include enzymatic and non-enzymatic antioxidants that are usually effective in blocking harmful effects of ROS. Enzymatic system includes enzymes such as superoxide dismutase (SOD), catalase (CAT), glutathione S-transferase (GST), glutathione peroxidase (GPx), and glutathione reductase (GR), which have also been reported to occur in bees (Weirich et al. 2002; Strachecka et al. 2014; Strachecka et al. 2017). Increased levels of antioxidant enzymes would, therefore, be indicative of an organism's attempt to respond to an oxidative stress condition.

In the present study, imidacloprid increased the activity of the GPx and CAT in the thorax of bees at both doses used, indicating induction of oxidative stress. These effects are in accordance with those described by Kapoor et al. (2010), who 


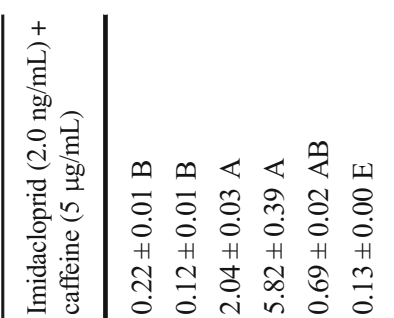

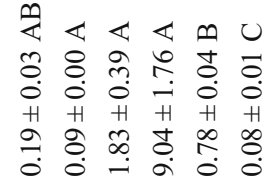

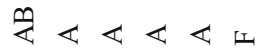

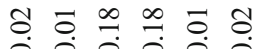

$\begin{array}{llllll}0 & 0 & 0 & 0 & 0 & 0 \\ 0_{H} & H & H & H & H & H\end{array}$

芶营

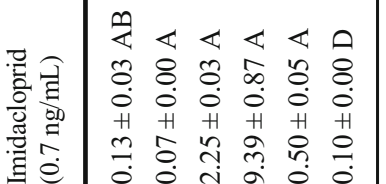

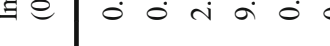

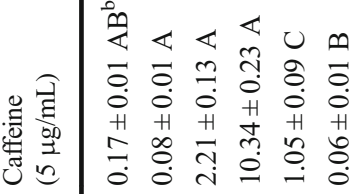

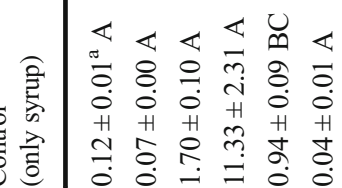

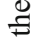

용

蒫 demonstrated an increase in the activity of GPx, CAT, and superoxide dismutase (SOD) enzymes in liver and brain of rats, and Kapoor et al. (2011), who demonstrated an increased activity of the same enzymes in the ovary of rats submitted to treatment with the insecticide for 90 days. El-Gendy et al. (2010) also reported increased activity of GPx, CAT, SOD, and glutathione Stransferase (GST) antioxidant enzymes in male mice $24 \mathrm{~h}$ after treatment with a single dose of imidacloprid.

Caffeine also promoted an increase in the activity of GPx and CAT enzymes. These results are in agreement with those described by Strachecka et al. (2014), who found that the use of caffeine in bee feeding increased the activity of the antioxidant enzymes GPx, CAT, SOD, and GST. The addition of caffeine together with imidacloprid promoted a change in the effects caused by the insecticide only on GPx activity, which was increased when caffeine was added at the $2.0 \mathrm{ng} /$ $\mathrm{mL}$ imidacloprid, probably due to an additive effect of both compounds.

GSH and NADPH are important components of the non-enzymatic antioxidant system, providing reductive equivalents for the action of the GPx and GR enzymes, respectively (Ribeiro et al. 2005). The treatment of bees with imidacloprid showed no effect on GSH and GSSG concentrations in relation to the control group, unlike other studies, which reported a decrease in the concentration of GSH in different animal tissues after treatments with the insecticide (Kapoor et al. 2010; Kapoor et al. 2011; ElGendy et al. 2010). There are multiple potential reasons for the divergence of our results from those of the earlier studies, including differences in study population, doses, and exposure times used. Caffeine alone also did not promote changes in GSH and GSSG concentrations. However, there was a significant increase in GSH and GSSG concentrations at the $2.0-\mathrm{ng} / \mathrm{mL}$ imidacloprid dose with the inclusion of caffeine. However, when the GSH/GSSG ratio was calculated, there was no significant effect of any of the treatments used in the present study. There was also no significant change in $\mathrm{NAD}(\mathrm{P}) \mathrm{H}$ concentration in the homogenate of the thorax in any of the treatments compared to the control group. 
Table III. The average intake of syrup with additives by honey bees for $24 \mathrm{~h}$

Caffeine $(5 \mu \mathrm{g} / \mathrm{mL})$

$9.83 \pm 2.40 \mathrm{~A}$

Imidacloprid $(0.7 \mathrm{ng} / \mathrm{mL})$

$10.95 \pm 4.14 \mathrm{~A}$

Imidacloprid $(2.0 \mathrm{ng} / \mathrm{mL})$

$26.90 \pm 2.04 \mathrm{~B}^{\mathrm{b}}$

Imidacloprid $(0.7 \mathrm{ng} / \mathrm{mL})+$ caffeine $(5 \mu \mathrm{g} / \mathrm{mL})$

$12.41 \pm 2.56 \mathrm{~A}$

Imidacloprid $(2.0 \mathrm{ng} / \mathrm{mL})+$ caffeine $(5 \mu \mathrm{g} / \mathrm{mL})$

$15.76 \pm 2.22 \mathrm{~A}$

${ }^{\text {a }}$ Results are expressed as the mean \pm standard error of the mean of three replicates with 20 bees/experiment

${ }^{\mathrm{b}}$ Means in the same column followed by different letters differ from each other (Tukey test, $p<0.05$ )

These results indicate that the doses of imidacloprid tested in this study did not affect the oxidative status of these non-enzymatic antioxidants in the thorax of honey bees.

The action of oxidizing substances on proteins can lead to the oxidation of the thiol group (-SH) of the amino acid cysteine, causing aggregation and fragmentation of amino acids, leading to protein denaturation (Aksenov and Markesbery 2001; Leichert and Jakob 2004). These effects may cause the reduction or inactivation of enzyme activity and may cause damage to receptors, signal transduction pathways, and transport (Halliwell and Gutteridge 2007). We detected a significant reduction in the concentration of the thiols (-SH) groups of proteins in the thorax homogenate of bees treated with imidacloprid, compared to the control, indicating that there was oxidation of these groups. This effect is in agreement with the results obtained by Sauer et al. (2014), who evaluated the effect of neonicotinoids in rat liver. The addition of caffeine to the imidacloprid treatments protected the thiol groups against oxidation, indicating an antioxidant effect of the alkaloid.

ROS can react with the polyunsaturated fatty acids of lipid membranes and induce lipid peroxidation (LPO), which affects the physiological function of cell membranes. The end product of these reactions is malondialdehyde (MDA), a marker of LPO and consequently oxidative stress (Gaweł et al. 2004). In the present study, imidacloprid significantly induced the LPO in the thorax homogenate of bees, as observed by the increased MDA. A similar result was reported by El-Gendy et al. (2010), Kapoor et al. (2010), Kapoor et al. (2011), and Bal et al. (2012), who all found an increase in MDA concentration in different animal tissues after treatment with imidacloprid. Caffeine alone also induced LPO, which is in agreement with studies by Dianzani et al. (1991), which described the oxidation of liver lipids in rats treated with caffeine, and Gülçin (2008), who reported a pro-oxidant caffeine activity on emulsion fatty acids in vitro. However, when added to diets containing imidacloprid, caffeine reduced the formation of MDA, which indicates an antioxidant activity. In fact, several studies have shown a reduction in MDA concentration in serum, liver, heart, brain, and kidney of animals treated with caffeine (Lee 2000; Devasagayam et al. 1996; George et al. 1999; Karas and Chakrabarti 2001; Al Moutaery et al. 2003).

The imidacloprid $\mathrm{LD}_{50}$ values for bees are $3.7 \mathrm{ng}$ and $40.9 \mathrm{ng} / \mathrm{bee}$, for oral and by contact, respectively (Schmuck et al. 2001). The survival rate of the bees in the $72 \mathrm{~h}$ of the experimental period was not affected by any of the treatments. These data show that the doses of the insecticide provided in the diets did not cause significant mortality; however, a sublethal effect not previously described of this neonicotinoid in the honey bees, the induction of oxidative stress, was observed.

Kessler et al. (2015) observed that Apis mellifera bees are attracted to neonicotinoids, increasing their exposure to these substances, which act as a drug in the bees' brains. This preference was similar to the results obtained in our study, since there was an increase in the 
average consumption of the diet containing $2.0 \mathrm{ng} / \mathrm{mL}$ imidacloprid. The preference for food contaminated with neonicotinoids, the great use of these products in agriculture, and the great impact on the health of the bees reinforce the importance of studies with the aim of discouraging the use of imidacloprid in the field and also to mitigate the harmful effects to the bees by using natural substances such as caffeine, capable of counteract, even if partially, the sublethal effects of this insecticide.

According to the data obtained in this study, it can be concluded that imidacloprid affected the parameters related to oxidative stress in the honey bee's thorax (Apis mellifera L.) and that caffeine acted as an antioxidant, partially avoiding the damages caused by the insecticide. Therefore, the inclusion of caffeine in the diet provided to bees may be an important strategy in preventing the toxic effects of imidacloprid, especially when the hives are installed near crops that are attractive to bees. Although we did not test the effects of imidacloprid at colony level, any reduction in the worker bees foraging results in reduced colony productivity, and therefore may represent a possible threat to honeybee colony health, which is a cause for concern for the bee population decline, adversely affecting beekeeping, the environment, and consequently human life.

\section{AUTHOR'S CONTRIBUTIONS}

All authors conceived and designed experiments; KVBB, MM, PFVB, ARJSG performed experiments and analysis; KVBB, DN, and FEM wrote the paper and all authors revised and approved the final manuscript.

\section{COMPLIANCE WITH ETHICAL STANDARDS}

Conflict of interest The authors declare that they have no conflict of interest.

Stress oxydatif induit par l'imidaclopride chez les abeilles et l'action antioxydante de la caféine
Apiculture / insecticide / peroxydation lipidique / néonicotinoïdes / stress oxydatif/ effets toxiques

Imidacloprid-induzierter oxidativer Stress bei Honigbienen und die antioxidante Wirkung von Koffein

Bienenhaltung / Insektizid / Lipidperoxidation / Neonikotinoide / oxidativer Stress / toxische Effekte

\section{REFERENCES}

Aebi, H. (1974). Catalase, in: Bergmeyer, H. U. Methods of Enzymatic Analysis, Academic Press, New York, pp. 673-677

Aizen, M. A., Harder, L. D. (2009) The global stock of domesticated honey bees is growing slower than agricultural demand for pollination. Curr. Biol. 19, 915918.

Aksenov, M. Y., Markesbery, W. R. (2001) Changes in thiol content and expression of glutathione redox system genes in the hippocampus and cerebellum in Alzheimer's disease. Neurosci. Lett. 302, 141-145

Al Moutaery, K., Al Deeb, S., Ahmad Khan, H., Tariq, M. (2003) Caffeine impairs short-term neurological outcome after concussive head injury in rats. Neurosurgery $\mathbf{5 3}, 704-711$

Albina, M. L., Colomina, M. T., Sanchez, D. J., Torrente, M., Domingo J. (2002) Interactions of caffeine and restraint stress during pregnancy in mice. Exp. Biol. Med. 227, 779-785

Bal, R., Türk, G., Tuzcu, M., Yilmaz, O., Kuloglu, T., Gundogdu, R., Gür, S., Agca, A., Ulas M., Çambay Z., Tuzcu, Z., Gencoglu, H., Guvenc, G., Ozsahin, A. D., Kocaman, N., Aslan A., Etem, E. (2012) Assessment of imidacloprid toxicity on reproductive organ system of adult male rats. J. Environ. Sci. Health Part B 47, 434-444

Blacker, T. S., Mann, Z. F., Gale, J. E., Ziegler, M., Bain, A. J., Szabadkai, G., Duchen, M. R. (2014) Separating $\mathrm{NADH}$ and NADPH fluorescence in live cells and tissues using FLIM. Nat. Commun. 5, 3936

Blacquière, T., Smagghe, G., van Gestel, C. A. M., Mommaerts, V. (2012) Neonicotinoids in bees: a review on concentrations, side-effects and risk assessment. Ecotoxicology 21, 973-992

Brittain, C., Potts, S. G. (2011) The potential impacts of insecticides on the life-history traits of bees and the consequences for pollination. Basic. Appl. Ecol. 12, $321-331$

Buege, J. A., Aust, S. D. (1978) Microsomal lipid peroxidation. Methods Enzymol. 52, 302-310

Cain K., Skilleter, D. N. (1987) Preparation and use of mitochondria in toxicological research, in: Snell K., 
Mullock, B. Biochemical Toxicology, IRL Press, Oxford, pp. 217-251

D'amicis, A., Viani, R. (1993) The consumption of coffee, in: Garattini S., Coffee, caffeine and health. Raven Press, New York, pp. 1-41

Decourtye, A., Lacassie, E., Pham-Delègue, M. H. (2003) Learning performances of honey bees are differentially affected by imidacloprid according to the season. Pest. Manag. Sci. 59, 269-278

Decourtye, A., Devillers, J., Cluzeau, S., Charreton, M., Pham-Delègue, M. H. (2004) Effects of imidacloprid and deltamethrin on associative learning in honeybees under semi-field and laboratory conditions. Ecotoxicol. Environ. Saf. 57, 410-419

Desneux, N., Decourtye, A., Delpuech, JM. (2007) The sublethal effects of pesticides on beneficial arthropods. Annu. Rev. Entomol. 52, 81-106.

Devasagayam, T. P. A., Kamat, J. P., Mohan, H., Kesavan, P. C. (1996) Caffeine as an antioxidant, inibition of lipid peroxidation induced by reactive oxygen species. Biochim. Biophys. Acta 1282, 63-70

Dianzani, M. U., Muzio, G., Biocca, M. E., Canuto, R. A. (1991) Lipid peroxidation in fatty liver induced by caffeine in rats. Int. J. Tissue. React. 13, 79-85

El-Gendy, K. S., Aly, N. M., Mahmoud, F. H., Kenawy, A., El-Sebae, A. K. (2010) The role of vitamin C as antioxidant in protection of oxidative stress induced by imidacloprid. Food. Chem. Toxicol. 48, 215-221

Farjan M., Dmitryjuk M., Lipiński, Z., Biernat-Łopieńska, E., Żółtowska, K. (2012) Supplementation of the honey bee diet with vitamin $\mathrm{C}$ : The effect on the antioxidative system of Apis mellifera carnica brood at different stages. J. Apicult. Res. 51, 263-270

Faucon, J. P., Aurières, C., Drajnudel, P., Mathieu L., Ribière M., Martel A. C., Zeggane S., Chauzat, M. P., Aubert, M. F. (2005) Experimental study on the toxicity of imidacloprid given in syrup to honey bee (Apis mellifera) colonies. Pest. Manag. Sci. 61, 111125

Flohé, L. G. W. A. (1984) Assays of glutathione peroxidase. Methods Enzymol. 105, 114-121

Gallai, N., Salles, J., Settele, J.,Vaissière, B. (2009) Economic evaluation of the vulnerability of world agriculture confronted with pollinator decline. Ecol. Econ. 68, 810-821

Gaweł, S., Wardas, M., Niedworok, E., Wardas, P. (2004) Malondialdehyde (MDA) as a lipid peroxidation marker. Wiad. Lek. 57, 453-455

George, K. C., Hebbar, S. A., Kale, S. P., Kesavan, P. C. (1999) Caffeine protects mice against whole-body lethal dose of $\gamma$-irradiation. J. Radiol. Prot. 19, 171-176

Gill, J. R., Ramos-Rodriguez, O., Raine, N. E. (2012) Combined pesticide exposure severely affects individual- and colony- level traits in bees. Nature 491, 105-108

Gülçin, I. (2008) In vitro prooxidant effect of caffeine. J. Enzym. Inhib. Med. Chem. 23, 149-152
Halliwell B., Gutteridge, J. M. C. (2007) Free radicals in biology and medicine. Oxford University Press, Oxford.

Hissin, P. J., Hilf, R. (1976) A fluorometric method for determination of oxidized and reduced glutathione in tissues. Anal. Biochem. 74, 214-226

Hodgson, E., Smart, R. C. (2001) Introduction to biochemical toxicology, in: Wiley-Interscience (3 Eds.), Hoboken, pp. 309-323

Hoskins, D. D., Chehldelin, V. H., Newburgh, R. W. (1956) Oxidative enzyme systems of the honey bee, Apis mellifera. L. J. Gen. Physiol. 39, 705-713

Johnson, R. M., Elis, M. D., Mullin, C. A., Fraizier, M. (2010) Pesticides and honey bee toxicity-USA. Apidologie 41, 312-331

Kapoor, U., Srivastava, M. K., Bhardwaj, S., Srivastava, L. P. (2010) Effect of imidacloprid on antioxidant enzymes and lipid peroxidation in female rats to derive its No Observed Effect Level (NOEL). J Toxicol. Sci. 35, 577-581

Kapoor, U., Srivastava, M. K., Srivastava, L. P. (2011) (Org.) Toxicological impact of technical imidacloprid on ovarian morphology, hormones and antioxidant enzymes in female rats. Food. Chem. Toxicol. 49, 3086-3089

Karas, M., Chakrabarti, S. K. (2001) Influence of caffeine on allyl alcohol induced hepatotoxicity in rats. In vivo study. J. Environ. Pathol. Tox. 20, 141-154

Kessler, S. C., Tiedeken, E. J., Simcock, K. L., Derveau, S. (2015) Bees prefer foods containing neonicotinoid pesticides. Nature 521, 74-76

Kiljanek, T., Niewiadowska, A., Posyniak, A. (2016) Pesticide poisoning of honeybees: A review of symptoms, incident classification, and causes of poisoning. J. Apic. Sci. 60, 5-24

Kremen, C., Williams, N. M., Aizen, M. A., GemmillHerren, B., LeBuhn, G., Minckley, R., Packer, L., Potts, S. G., Roulston, T., Steffan-Dewenter, I., Vázquez, D. P., Winfree, R., Adams, L., Crone, E. E., Greenleaf, S. S., Keitt, T. H., Klein, A-M., Regetz, J., Ricketts, T. H. (2007) Pollination and other ecosystem services produced by mobile organisms: a conceptual framework for the effects of land-use change. Ecol. Lett. 10, 299-314

Krupke, C. H., Hunt, G. J.; Eitzer, B. D.; Andino, G.; Given, Krispn (2012). Multiple Routes of Pesticide Exposure for Honey Bees Living Near Agricultural Fields. PLoS one 7, e29268.

Lee, C. (2000) Antioxidant ability of caffeine and its metabolites based on the study of oxygen radical absorbing capacity and inhibition of LDL peroxidation. Clin. Chim. Acta 295 , 141-154

Leichert, L. I., Jakob, U. (2004) Protein thiol modifications visualized in vivo. Plos Biol. 2, 1723-1737

Matsuda, K., Buckingham, S. D., Kleiner, D., Rauh, J.J., Grauso, M., Sattelle, D. B. (2001) Neonicotinoids: insecticides acting on insect nicotinic acetylcholine receptors. Trends Pharmacol. Sci. 22, 573-580 
Mcgregor, S. E. (1976) Insect pollination of cultivated crop plants: Agriculture handbook 496. USDA - Agricultural Research Service, Washington, D.C. pp. 411

Morandin, L. A., Winston, M. L. (2006) Pollinators provide economic incentive to preserve natural land in agroecosystems. Agric. Ecosyst. Environ. 116, 289292

Nicholls, C. I., Altieri, M. A. (2013) Plant biodiversity enhances bees and other insect pollinators in agroecosystems. A review. Agron. Sustain. Dev. 33, 257-274

Nicodemo, D., Maioli, M. A., Medeiros, H. C., Guelfi M., Balieira, K. V., De Jong, D., Mingatto, F. E. (2014) Fipronil and imidacloprid reduce honeybee mitochondrial activity. Environ. Toxicol. Chem. 33 , 2010-2075

Nicodemo, D., De Jong, D., Reis, L. G., Almeida, J. M. V., Santos, A. A., Lisboa, L. A. M. (2018) Transgenic corn decreased total and key storage and lipid transport protein levels in honey bee hemolymph while seed treatment with imidacloprid reduced lipophorin levels. J. Apic. Res. 57, 321-328

Paoletti, M. G. (1999) Invertebrate Biodiversity as Bioindicators of Sustainable Landscapes: Practical Use of Invertebrates to Assess Sustainable Land Use. Elsevier, New York.

Pham-Delègue, M., Decourtye, A., Kaiser, L., Devillers, J. (2002) Behavioural methods to assess the effects of pesticides on honey bees. Apidologie 33, 425-432

Poquet, Y., Vidau, C., Alaux, C. (2016) Modulation of pesticide response in honeybees Apidologie 47, 412426

Ribeiro, S. M. R., Queiroz, J. H., Peluzio, M. C. G., Costa, N. M. B., Matta, S. L. P., Queiroz, M. E. L. R. (2005) A formação e os efeitos das espécies reativas de oxigênio no meio biológico. Biosci. J. 21,133-149

Rortais, A., Arnard, G., Halm, M., Touffet-Briens, F. (2005) Modes of honey bees exposure to systemic insecticides, estimated amounts of contaminate a pollen and nectar consumed by different categories of bees. Apidologie 36, 71-83

Sauer, E., Moro, A. M., Brucker, N., Nascimento, S., Gauer B., Fracasso, R. (2014) Liver $\sigma$-aminolevulinate dehydratase activity is inhibited by neonicotinoids and restored by antioxidant agents. Int. J. Env. Res. Pub. He. 11, 11676-11690

Schmuck, R., Schoning, R., Stork, A., Schramel, O. (2001) Risk posed to honeybees (Apis mellifera) by an imidacloprid seed dressing of sunflowers. Pest. Manag. Sci. 57, 225-238

Sedlak, J., Lindsay, R. H. (1968) Estimation of total, protein-bound and nonprotein sulfhydryl groups in tissue with Ellman's reagent. Anal. Biochem. 25, 192-205

Strachecka, A., Krauze M., Olszewski, K., Borsuk, G., Paleolog, J., Merska M., Chobotow, J., Bajda, M., Grzywnowicz, K. (2014) Unexpectedly strong effect of caffeine on the vitality of western honeybees (Apis mellifera ). Biochemistry (Mosc) 79, 1192-1201

Strachecka, A. J., Olszewski, K., Paleolog, J. (2015) Curcumin stimulates biochemical mechanisms of Apis mellifera resistance and extends the apian life-span. J. Apic. Sci. 59 (1), 129-141

Strachecka, A., Chobotow, J., Paleolog J., Èoś A., Schulz M., Teper D., Kucharczyk H., Grzybek, M. (2017) Insights into the biochemical defence and methylation of the solitary bee Osmia rufa L, a foundation for examining eusociality development. PLoS One 12, $1-23$

Thompson, H. M. (2001) Assessing the exposure and toxicity of pesticides to bumble bees (Bombus sp.). Apidologie 32, 305-321

Thompson, H. M. (2002) Behavioral effects of pesticides in bees, their potential for use in risk assessment. Ecotoxicology 12, 317-333

Van Der Sluijs, J. P., Simon-Delso, N., Goulson, D., Maxim, L. Bonmatin, J. M., Belzunces, L. P. (2013) Neonicotinoids, bee disorders and the sustainability of pollinator services. Curr. Opin. Environ. Sustain. 5, 293-305

Van Der Steen, J. J. M. (2001) Review of the methods to determine the hazard and toxicity of pesticides to bumble bees. Apidologie 32, 399-406

Weirich, G. F., Collins, A. M., Williams, V. P. (2002) Antioxidant enzymes in the honey bee, Apis mellifera . Apidologie 33, 3-14 